\section{Plant Density and Nitrogen Fertilizer Rate on Yield and Nutrient Content of Onion Developed from Greenhouse-grown Transplants}

\author{
Vincent M. Russo ${ }^{1}$ \\ U.S. Department of Agriculture, Agricultural Research Service, South \\ Central Agricultural Research Laboratory, 911 Highway 3W, Lane, OK \\ 74555
}

Additional index words. bareroot, hoop-house, Candy, Texas Grano 1015 Y

\begin{abstract}
Onions (Allium cepa L.) can be established from seed or transplants. The latter planting material can be dormant or actively growing when transplanted to the field. Onion transplants can be produced in a greenhouse, but additional information is needed regarding the cultural requirements after transplanting. Greenhouse-grown transplants of 'Candy', intermediate-day variety, and 'Texas Grano 1015 Y', short-day variety, were established at densities of $\approx 34,000,68,000$, or 102,000 plants/ha and 100 (recommended) and $400 \mathrm{~kg} \cdot \mathrm{ha}^{-1}$ of nitrogen in mid-March of 2006 and 2007. Nitrogen fertilizer rate did not affect yield. Yield of 'Candy' was greater than for 'Texas Grano 1015 Y'. Yield of both cultivars increased as density increased, and yield of 'Texas Grano $1015 \mathrm{Y}$ ' was higher in 2006 than in 2007. 'Candy' had higher numbers of large-sized bulbs and 'Texas Grano 1015 Y' more small bulbs. Bulb nutrient content was affected by year with nitrate$\mathrm{N}$, potassium, sodium, and $\mathrm{SO}_{4}$ being higher in 2006 and nitrite-N, calcium, magnesium, $\mathrm{PO}_{4}$, and soluble solids higher in 2007 . 'Candy' had a higher soluble solids ( ${ }^{\circ} \mathrm{Brix}$ ) content than did 'Texas Grano 1015 Y'. In 2007, precipitation was higher than in 2006. This may have contributed to the year response and it appears that 'Candy' was better able to respond in a more uniform manner to the changed environmental conditions. For plants developed from greenhouse-grown transplants, the recommended rate of fertilizer and the highest plant density are beneficial to improved marketable yield.
\end{abstract}

In parts of the United States, onions (Allium cepa L.) can be seeded in the late fall and overwintered in the field for harvest in the spring (Boyhan et al., 2007) or seeded in early spring for harvest in the fall (Wang et al., 2008). Establishment of onions with fall seeding has had mixed success locally (McCraw, 1990; Shrefler, 2001, 2004). For onions grown from seed, it has been reported that yield is improved when: straw mulch is applied to tire track areas when furrow irrigation is used (Shock et al., 1999), plastic is used (Vavrina and Roka, 2000), drip irrigation was applied at $1.27 \mathrm{~cm}$ per application with an emitter flow rate of $0.5 \mathrm{~L} \cdot \mathrm{ha}^{-1}$ (Shock et al., 2005), planting was with a companion crop to prevent wind damage (Hatterman-Valenti and Hendrickson, 2006), and onion followed Brassica and Sorghum cover crops (Wang et al., 2008).

For commercial production on a large scale, the common characteristic of all planting material is that it be able to continue to develop after being established in the field. In some, but not all, onion planting areas (Boyhan et al., 2001a), seedlings are established in the field with a mechanical trans-

Received for publication 11 Feb. 2008. Accepted for publication 10 June 2008.

${ }^{1}$ To whom reprint requests should be addressed; e-mail vrusso-usda@lane-ag.org planter. If this is the case, the planting material must be compatible with the equipment. The method of transplant production may also affect growth once plants are established in the field (Russo, 2004). The condition of the plant could affect how quickly growth is resumed and potentially how long the plant will have to stay in the field before harvest.

The term bareroot transplant is applied to a type of onion planting material used for commercial production and which can be established with a mechanical transplanter. If the term transplant was used for other crops, i.e., cucurbits, peppers, tomatoes, it would be understood that the seedlings had likely been grown in a greenhouse and the apical tip and roots would be actively growing. For bareroot onion transplants, this is not the case. Bareroot transplants are generally wintering bed, had the tops clipped, and been subjected to some degree of drying. As a result, the meristem that gives rise to leaves may be dormant. In addition, the roots may have been clipped and are either not actively growing or exhibiting much reduced growth. Yield of plants developed from organically produced bareroot transplants was less than for plants grown with handweeding (Boyhan et al., 2006). Also, when bareroot transplants were used, it was determined that growth stimulants did not affect yield from plants considered to have been lifted from an over- that developed from them (Boyhan et al., 2001b).

Onion transplants can also be produced in a hoop-house (Shrefler et al., 2007b) where seed is sown into beds in the hoop-house in the fall and overwintered for establishment in the field in early spring. This type of structure is generally unheated and comprised of plastic drawn over supports. Plants produced in a hoop-house are grown in close proximity and on lifting may have the tops and roots clipped, have bare roots, and are not dried for an appreciable length of time before being established in the field.

Production of transplants in seedling trays in a greenhouse could be an alternative to other methods of producing onion planting material. In some locations in the United States, transplanting onions in late winter is preferred (Leskovar and Vavrina, 1999; Russo, 2004). Generally, beneficial results to yield with the use of greenhouse-grown onion transplants have been described (Kanton et al., 2002; Leskovar and Vavrina, 1999; Russo, 2004). In Michigan, when there were two seedlings in each cell in the seedling tray, and increased nitrogen fertilizer was used during seedling production, yield of plants developed from these seedlings increased over those that developed from a single seedling per cell (Herison et al., 1993).

Onion is a relatively new crop for this region and several aspects of their production need to be quantified and/or optimized. One factor is the fertilizer requirement; it is necessary to determine whether recommended amounts are sufficient. In solution culture, the ratio of ammonium-N to nitrate-N affected plant development, water uptake, and pyruvate and sulfur concentration (Gamiely et al., (1991). Conditions in the field differ from greenhouse culture and it is necessary to determine rates of fertilizer needed for optimum yield. Boyhan et al. (2007), using bareroot transplants, indicated that increasing fertilizer rate by $\approx 2.25 \times$ did not appreciably increase yield, but increased nitrogen, phosphorus, and potassium affected levels of some nutrients in leaf tissue. For seeded plants, additional nitrogen fertilizer rate increased bulb decay (Díaz-Pérez et al., 2003) but did not affect yield (Shock et al., 2004). Maier et al. (1990a, 1990b) applied up to $475 \mathrm{~kg} \cdot \mathrm{ha}^{-1}$ of nitrogen to seeded onion established on siliceous soil and found a relationship between increasing tissue nitrogen and yield as nitrogen fertilizer rate increased. The soils at Lane, $\mathrm{OK}$, are also siliceous, but it is not clear if the higher amounts of nitrogen fertilizer would be beneficial to plants developed from greenhouse-grown transplants.

Whether plants compete for space, water, nutrients, or sun is largely dependent on how many plants are present. For plants grown from seed, yields increased as plant density increased (Bleasdale, 1966), but large bulb yields decreased as density increased (Shock et al., 2004). However, when bareroot transplants were used, it was found that onion yields increased as plant density increased (Brewster and Salter, 1980). For greenhouse-grown 
transplants, increasing plant density reduced yield of large-sized bulbs (Stoffella, 1996). At Lane, OK, yields of plants developed from greenhouse-grown, and bareroot, transplants, established at the same plant density, were not different (Russo, 2004).

The requirements for planting material production using the different growing methods (Table 1) could affect cost of transplant production and might affect acceptance of the type of planting material used. To determine if use of greenhouse-grown transplants affects subsequent yield, it is necessary to better understand how cultural methods affect plants after establishment in the field. This project was undertaken to determine effects of nitrogen fertilizer rate and plant density on yield of plants of onion cultivars developed from greenhouse-grown transplants and how treatment affected bulb nutrient content.

\section{Materials and Methods}

Greenhouse-grown transplants of 'Texas Grano 1015 Y', a short-day cultivar, and
'Candy', an intermediate-day cultivar, onions were produced using the procedures of Russo (2004) with the exception that seedlings were maintained in 128-cell trays, $36 \mathrm{~cm}^{3} /$ cell (Speedling $^{\circledR}$; Oklahoma Plant Products, Oklahoma City, OK), for 12 rather than 8 weeks. Seed were sown on 15 Dec. 2006 and 14 Dec. 2007 in a commercially available potting medium (Reddi-Earth; Scotts-Sierra Horticultural Products, Marysville, OH). Fertilization was begun $\approx 2$ weeks after sowing and continued weekly with half-strength Peter's Soluble Fertilizer (20-20-20; Spectrum Group, United Industries Corp., St. Louis, MO). Irrigation was twice a day for 3 min per application with overhead misters.

Transplant age used was based on the best estimation of yield from other research in which seedling ages ranged from 4 to 12 weeks (Brewster, 1994; Herison et al., 1993; Kanton et al., 2002; Leskovar and Vavrina, 1999). Before transplanting at the three- to four-leaf stage, 10 randomly chosen seedlings from each cultivar were put aside. The growing medium was washed from the roots. Fresh weights were determined and trans-

Table 1. Comparison of cultural activities to produce onion transplants and to produce bulbs from planting material acquired from commercial sources (bunched plant, transplant) or produced in a hoop-house or greenhouse.

\begin{tabular}{|c|c|c|c|}
\hline \multirow[b]{2}{*}{ Activity } & \multicolumn{3}{|c|}{ Type of planting material } \\
\hline & $\begin{array}{l}\text { Bareroot bunched } \\
\text { plant (transplant) }\end{array}$ & $\begin{array}{l}\text { Hoop-house } \\
\text { grown }\end{array}$ & $\begin{array}{l}\text { Greenhouse } \\
\text { grown }\end{array}$ \\
\hline \multicolumn{4}{|l|}{ Transplant production } \\
\hline Location & On or off-farm ${ }^{z}$ & On or off-farm & On or off-farm \\
\hline Structure & None & Hoop-house & Greenhouse \\
\hline Seed & Required & Required & Required \\
\hline Thinning stand & Not required & Not required & To one plant/cell \\
\hline Growing medium & Soil & Soill $^{\mathrm{y}}$ & Potting mix in trays \\
\hline Establishment & Tractor-mounted seeder & Handheld seeder & By hand \\
\hline Fertilizer & Required & Required & Required \\
\hline Irrigation & Required $^{\mathrm{x}}$ & Required & Required \\
\hline Weed control & Possibly & Possibly & None \\
\hline Temperature control & None & None & Required \\
\hline $\begin{array}{l}\text { Length of production period } \\
\text { Pre-plant treatment }\end{array}$ & $\begin{array}{l}\text { Late fall to late } \\
\text { winter }\end{array}$ & $\begin{array}{l}\text { Late fall to late } \\
\text { winter }\end{array}$ & Mid- to late winter \\
\hline Preplant treatment & $\begin{array}{l}\text { Lifting, separation, } \\
\text { clipping of roots } \\
\text { and tops, drying } \\
\text { before shipping, } \\
\text { bunching }\end{array}$ & $\begin{array}{l}\text { Lifting, separation, } \\
\text { clipping of root } \\
\text { and tops }\end{array}$ & $\begin{array}{l}\text { Moved outside } \\
\text { to harden off, } \\
\text { possible clipping }\end{array}$ \\
\hline $\begin{array}{l}\text { Approximate number } \\
\text { of transplants } \\
\text { produced } / \mathrm{m}^{2}\end{array}$ & Up to $900^{w}$ & $880^{\mathrm{v}}$ & $800^{\mathrm{u}}$ \\
\hline \multicolumn{4}{|l|}{ Field $^{\mathrm{t}}$} \\
\hline Soil preparation & Required & Required & Required \\
\hline Preplant fertilization & Required & Required & Required \\
\hline Herbicide & Required & Required & Required \\
\hline Establishment in field & Transplanter & Transplanter & Transplanter \\
\hline \multicolumn{4}{|l|}{ Crop field maintenance ${ }^{t}$} \\
\hline Pest control & If required & If required & If required \\
\hline Additional fertilization & If required & If required & If required \\
\hline Cultivation & If required & If required & If required \\
\hline Irrigation & If required & If required & If required \\
\hline Harvest $^{s}$ & Required & Required & Required \\
\hline
\end{tabular}

${ }^{\mathrm{z} C o m m e r c i a l ~ a c t i v i t y ~ d e s i g n e d ~ t o ~ p r o d u c e ~ t r a n s p l a n t s ~ f o r ~ p r o d u c e r s ~ a t ~ o t h e r ~ l o c a t i o n s . ~}$

${ }^{y}$ An augmented soil or soilless mix could be used, possibly in raised beds.

${ }^{x}$ Dependent on amount of precipitation; lack of irrigation detrimental in some locations (Singh and Cramer, 2006).

${ }^{\text {w} B e s t ~ e s t i m a t e ~ b a s e d ~ o n ~ s p a c i n g ~ u s e d ~ b y ~ c o m m e r c i a l ~ s u p p l i e r ~ a n d ~ p e r s o n a l ~ c o m m u n i c a t i o n ~(G . ~ B o y h a n) . ~}$

${ }^{\mathrm{v}}$ Based on spacing $\approx 80$ plants $/ \mathrm{m}$ of row $\times 11$ rows with rows on $10-\mathrm{cm}$ centers

uBased on 128-cell trays with $35 \times 35$-mm (length $\times$ width) cell dimensions and $36 \mathrm{~cm}^{3} / \mathrm{cell}^{\text {u }}$.

'The method should be the same regardless of type of transplant used.

sTime to harvest may vary. plants were placed individually in paper bags and then into a forced air oven at $32{ }^{\circ} \mathrm{C}$ until dry weights were stabilized. To accommodate seedings in the transplanter (Holland Co., Holland, MI), tops were trimmed in both years to $\approx 15 \mathrm{~cm}$ and allowed to regrow for 2 weeks before establishment in the field. Transplants were moved to the field on 15 Mar. 2006 and 12 Mar. 2007.

The field experiment was conducted at Lane, OK, on a Bernow fine-loamy, siliceous, thermic Glossic Paleudalf soil. A base rate of fertilizer was added in both years to bring soil residual fertilizer levels to $100 \mathrm{~N}-112 \mathrm{P}-212 \mathrm{~K}$ $\mathrm{kg} \cdot \mathrm{ha}^{-1}$ in response to soil test results (Motes and Roberts, 1994). The source of nitrogen was ammonium nitrate (34-0-0), phosphorus was soluble triple superphosphate $(0-46-0)$, and potassium was muriate of potash (00-60). Fertilizer was incorporated with a multifunction soil preparation implement (Do-All, Forrest City, AR). After disking, rough beds were formed with a hiller-furrower (Powell Manufacturing, Bennettsville, $\mathrm{SC}$ ). Finished beds on 1.9-m centers, formed with a Tillovator and bed-shaper (Ferguson, Suffolk, VA), were $15.25 \mathrm{~cm}$ high, $\approx 1.6 \mathrm{~m}$ across the top and oriented north to south.

There was one, two, or three rows/bed. When established in a single row, seedlings were placed in bed centers. When established in two rows, seedlings were planted $\approx 15 \mathrm{~cm}$ in from each edge of the bed. When established in three rows, the seedlings were planted $\approx 15 \mathrm{~cm}$ in from each edge of the bed and in the middle of the bed. Individual plots were $3.1 \mathrm{~m}$ long. There were 20,40 , or 60 plants per plot, which corresponded to plant populations of $\approx 34,000,68,000$, or 102,000 plants/ha, respectively. Guard rows were planted on the east and west, and there were $1 \mathrm{~m}$ in-row alleys between plots. Within 1 month of transplanting, additional nitrogen (34-0-0) was applied at $300 \mathrm{~kg} \cdot \mathrm{ha}^{-1}$ to

Table 2. Analysis of variance responses resulting from year, cultivar, fertilizer rate, and plant density and the interactions on total marketable number and yield of onion developed from greenhouse-grown transplants.

\begin{tabular}{lcc}
\hline & \multicolumn{2}{c}{ Total marketable/ha } \\
\cline { 2 - 3 } Source & Number & Yield \\
\hline Year (Y) & NS & $*$ \\
Cultivar (C) & NS & $* *$ \\
Fertilizer rate (F) & $* *$ & NS \\
Plant density (D) & L, ${ }^{*}$ & $*$ \\
& & $\mathrm{~L},{ }^{*}$ \\
Interactions & NS \\
$\mathrm{Y} \times \mathrm{C}$ & $\mathrm{NS}$ & $*$ \\
$\mathrm{Y} \times \mathrm{F}$ & $\mathrm{NS}$ & $\mathrm{NS}$ \\
$\mathrm{Y} \times \mathrm{D}$ & $\mathrm{NS}$ & $\mathrm{NS}$ \\
$\mathrm{C} \times \mathrm{D}$ & $\mathrm{NS}$ & $\mathrm{NS}$ \\
$\mathrm{C} \times \mathrm{F}$ & $\mathrm{NS}$ & $\mathrm{NS}$ \\
$\mathrm{F} \times \mathrm{D}$ & $\mathrm{NS}$ & $\mathrm{NS}$ \\
$\mathrm{Y} \times \mathrm{C} \times \mathrm{F}$ & $\mathrm{NS}$ & $\mathrm{NS}$ \\
$\mathrm{Y} \times \mathrm{C} \times \mathrm{D}$ & $\mathrm{NS}$ & $\mathrm{NS}$ \\
$\mathrm{Y} \times \mathrm{F} \times \mathrm{D}$ & $\mathrm{NS}$ & $\mathrm{NS}$ \\
$\mathrm{C} \times \mathrm{F} \times \mathrm{D}$ & $\mathrm{NS}$ & $\mathrm{NS}$ \\
$\mathrm{Y} \times \mathrm{C} \times \mathrm{F} \times \mathrm{D}$ & $\mathrm{NS}$ \\
\hline $\mathrm{Ns}, * * * \mathrm{Nonsignificant}$ or significant at $P<0.01$ or \\
$P<0.05$, respectively, analysis of variance.
\end{tabular}

HortScience Vol. 43(6) OCtober 2008 

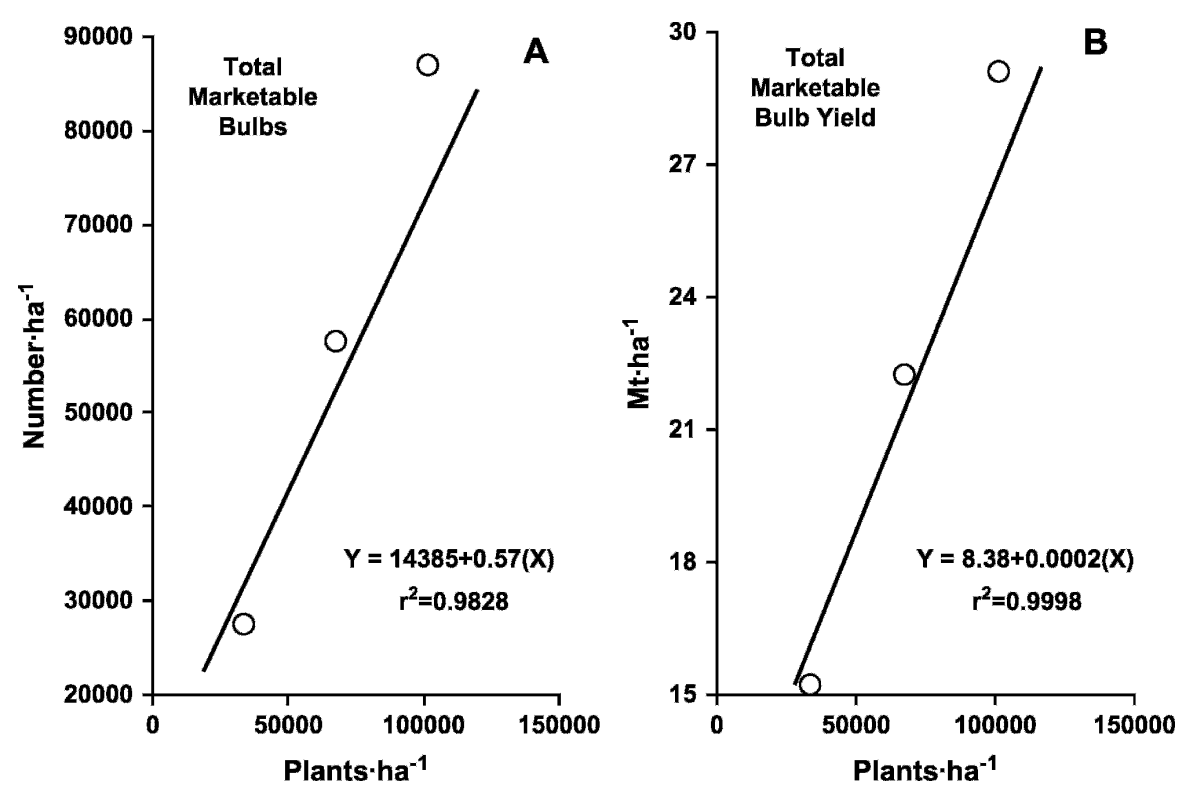

Fig. 1. Distribution of (A) number and (B) yield of total marketable bulbs from onion plants developed from greenhouse-grown transplants.

one-half of the plots. In 2007, the herbicide sethoxydim was applied 1 week after transplanting. After $\approx 1$ month after transplanting, the herbicides oxyfluoren and pendimethalin were applied over tops of plants in both years at rates recommended by the manufacturer. When needed, irrigation was applied at the rate of $\approx 5 \mathrm{~cm} /$ application supplied by overhead irrigation. No insecticides or fungicides were applied.

Bulbs were harvested when $50 \%$ of tops had broken over at the neck: 'Texas Grano 1015 Y' at 17 June 2006 and 14 June 2007 and 'Candy' at 27 June 2006 and 3 July 2007. At harvest, tops were cut $\approx 2 \mathrm{~cm}$ above the neck

Table 3. Effect of year, cultivar, and plant density on total marketable number of fruit and yield in onion developed from greenhouse-grown transplants.

\begin{tabular}{lcc}
\hline & \multicolumn{2}{c}{ Marketable } \\
\cline { 2 - 3 } Source & Number/ha & $\begin{array}{c}\text { Yield } \\
\left(\mathrm{mg} \cdot \mathrm{ha}^{-1}\right)\end{array}$ \\
\hline Year & & \\
2006 & $63,423 \mathrm{a}^{\mathrm{z}}$ & $24.4 \mathrm{a}$ \\
2007 & $59,403 \mathrm{a}$ & $19.7 \mathrm{~b}$ \\
Cultivar & & \\
$\quad$ Candy & $65,521 \mathrm{a}$ & $28.0 \mathrm{a}$ \\
$\quad$ Texas Grano & $60,308 \mathrm{a}$ & $16.4 \mathrm{~b}$ \\
$\quad$ 1015 Y & & \\
Interaction & & \\
$\quad$ Cultivar $\times$ year & & \\
$\quad$ Candy 2006 & $-\mathrm{y}$ & 28.4 \\
$\quad$ 2007 & - & $27.6 \mathrm{NS}$ \\
$\quad$ Texas Grano & - & 20.6 \\
$\quad$ 1015 Y 2006 & & $12.1 * *$ \\
$\quad 2007$ & - &
\end{tabular}

${ }^{\text {z}}$ Values in a column followed by the same letter are not significantly different, $P<0.05$, Ryan-EinotGabriel-Welsch multiple F-test.

y "_- = Interaction not significant for marketable number of bulbs or total soluble solids.

${ }^{\mathrm{Ns},}{ }^{* *}$ Values in a year $\times$ cultivar combination are nonsignificant or significantly different, $P>0.01$, least squares means analysis. and bulbs transported to a grading shed. Bulbs were distributed into classes by passing them through grading pallets with various sized holes. Marketable bulbs were distributed in the following size classes based on diameter: small, less than $50 \mathrm{~mm}$; medium, 50 to less than $75 \mathrm{~mm}$; large, 75 to less than $100 \mathrm{~mm}$; and jumbo, greater than 100 (U.S. Department of Agriculture, Agricultural Marketing Service, 1995). Culls were those in all size classes that were misshapen, below the small category in size, or that exhibited blemishes.

Subsamples of large-sized bulbs were separated, washed with tap water, dried, and split in half. Tissue from the middle bulb scales from one-half of the bulb was used to determine soluble solids ( ${ }^{\circ}$ Brix) with a refractometer (Pocket PAL-1; Atago U.S.A., Bellevue, WA). The other half of the bulb was cut into smaller portions and placed in paper bags and then into a forced air oven at $50{ }^{\circ} \mathrm{C}$ to dry until weight stabilized. After drying, tissues were ground with a hammer mill and passed through a 2-mm screen. Levels of calcium, potassium, magnesium, sodium, nitrate- $\mathrm{N}$, nitrite- $\mathrm{N}, \mathrm{PO}_{4}$, and $\mathrm{SO}_{4}$ were determined in subsamples of tissues. Tissues were treated with a water extract (Russo and Karmakar, 1998) and analysis was with a Lachat 8000 analytical system (Hach Co., Loveland, CO) in the ion chromatography mode using methods provided by Lachat (anions with QuikChem method 10-510-00-1-A; cations with QuikChem method 10-520-00-1-B). Total nitrogen (TKN) and total phosphorus (TKP) levels in a Kjeldahl digest were determined in tissues in other subsamples using the same machine in the flow injection analysis mode using methods provided by Lachat (TKN with QuikChem method 13-107-06-2-D; TKP with QuikChem method 13-115-01-1-B).

The experimental design was a split-split plot with fertilizer rate (2) comprising the main plot, cultivar (2) comprising the first split, and plant density (3) comprising the second split. There were three replications for each combination of plant density, nitrogen fertilizer rate, and cultivar. Data were analyzed with the general linear methods procedures in SAS (Version 7.1; SAS Institute, Cary, NC). When interactions occurred, they were used to explain results. If interactions did not exist, means were separated with the Ryan-Einot-Gabriel-Welsch multiple F-test. When it was determined that there was significance, linear regression was used to explain effects of density on measured variables, especially to determine if plant density could be increased. Precipitation and minimum, maximum, and average temperatures were recorded.

\section{Results}

'Candy' transplants were heavier, $\approx 0.45 \mathrm{~g}$, than were 'Texas Grano $1015 \mathrm{Y}$ ', $\approx 0.35 \mathrm{~g}$,

Table 4. Analysis of variance responses resulting from year, cultivar, fertilizer rate, and plant density and interactions on number of fruit and yield of categories of onion developed from greenhouse-grown transplants.

\begin{tabular}{|c|c|c|c|c|c|c|c|c|c|c|}
\hline \multirow[b]{2}{*}{ Source } & \multicolumn{2}{|c|}{ Small/ha } & \multicolumn{2}{|c|}{ Medium/ha } & \multicolumn{2}{|c|}{ Large/ha } & \multicolumn{2}{|c|}{ Jumbo/ha } & \multicolumn{2}{|c|}{ Cull/ha } \\
\hline & Number & Yield & Number & $\overline{\text { Yield }}$ & Number & Yield & Number & Yield & Number & Yield \\
\hline Year (Y) & $* *$ & $* *$ & NS & NS & $* *$ & $* *$ & NS & NS & NS & $*$ \\
\hline Cultivar (C) & $* *$ & $* *$ & $* *$ & $* *$ & $* *$ & $* *$ & $* *$ & $* *$ & NS & $* *$ \\
\hline Fertilizer rate $(\mathrm{F})$ & NS & NS & NS & NS & NS & NS & NS & NS & NS & NS \\
\hline Plant density (D) & $*$ & $*$ & $* *$ & $* *$ & $*$ & $* *$ & NS & NS & NS & NS \\
\hline & $\mathrm{L}, * *$ & $\mathrm{~L}, * *$ & $\mathrm{~L}, * *$ & $\mathrm{~L}, * *$ & $\mathrm{~L}, * *$ & $\mathrm{~L}, * *$ & $\mathrm{NL}$ & $\mathrm{NL}$ & $\mathrm{NL}$ & $\mathrm{NL}$ \\
\hline Interactions & & & & & & & & & & \\
\hline $\mathrm{Y} \times \mathrm{C}$ & $* *$ & $* *$ & NS & NS & $*$ & NS & NS & NS & NS & $* *$ \\
\hline $\mathrm{Y} \times \mathrm{F}$ & NS & NS & NS & NS & $*$ & NS & NS & NS & NS & NS \\
\hline $\mathrm{C} \times \mathrm{D}$ & NS & NS & NS & NS & NS & NS & NS & NS & NS & NS \\
\hline $\mathrm{C} \times \mathrm{F}$ & NS & NS & NS & NS & NS & NS & NS & NS & NS & NS \\
\hline $\mathrm{Y} \times \mathrm{D}$ & NS & NS & NS & NS & NS & NS & NS & NS & NS & NS \\
\hline $\mathrm{F} \times \mathrm{D}$ & NS & NS & NS & NS & NS & NS & NS & NS & NS & NS \\
\hline $\mathrm{Y} \times \mathrm{C} \times \mathrm{D}$ & NS & NS & NS & NS & NS & NS & NS & NS & NS & NS \\
\hline $\mathrm{Y} \times \mathrm{F} \times \mathrm{D}$ & NS & NS & NS & NS & NS & NS & NS & NS & NS & NS \\
\hline $\mathrm{Y} \times \mathrm{C} \times \mathrm{F}$ & NS & NS & NS & NS & NS & NS & NS & NS & NS & NS \\
\hline $\mathrm{C} \times \mathrm{F} \times \mathrm{D}$ & NS & NS & NS & NS & NS & NS & NS & NS & NS & NS \\
\hline $\mathrm{Y} \times \mathrm{C} \times \mathrm{F} \times \mathrm{D}$ & NS & NS & NS & NS & NS & NS & NS & NS & NS & NS \\
\hline
\end{tabular}

Ns,*, *** Nonsignificant or significant at $P<0.01$ or $P<0.05$, respectively, analysis of variance. 
Table 5. Main and interaction effects as they affected number of fruit and yield of categories of onion developed from greenhouse-grown transplants.

\begin{tabular}{|c|c|c|c|c|c|c|c|c|c|c|}
\hline \multirow[b]{2}{*}{ Source } & \multicolumn{2}{|c|}{ Small/ha } & \multicolumn{2}{|c|}{ Medium/ha } & \multicolumn{2}{|c|}{ Large/ha } & \multicolumn{2}{|c|}{ Jumbo/ha } & \multicolumn{2}{|c|}{ Cull/ha } \\
\hline & Number & $\overline{\text { Yield }}$ & Number & $\overline{\text { Yield }}$ & Number & $\overline{\text { Yield }}$ & Number & Yield & Number & Yield \\
\hline 2006 & $407 b^{z}$ & $0.04 \mathrm{a}$ & $19,361 \mathrm{a}$ & $5.4 \mathrm{a}$ & 29,449 a & $14.0 \mathrm{a}$ & $14,318 \mathrm{a}$ & $10.7 \mathrm{a}$ & 1,988 a & $0.06 \mathrm{~b}$ \\
\hline Texas Grano $1015 \mathrm{Y}$ & $3,417 \mathrm{a}$ & $0.25 \mathrm{a}$ & $31,238 \mathrm{a}$ & $7.9 \mathrm{a}$ & $22,778 \mathrm{~b}$ & $9.9 \mathrm{~b}$ & $2,846 \mathrm{~b}$ & $2.0 \mathrm{~b}$ & $2,071 \mathrm{a}$ & $0.22 \mathrm{a}$ \\
\hline Candy & $683 \mathrm{~b}$ & $0.06 \mathrm{~b}$ & $10,576 \mathrm{~b}$ & $2.9 \mathrm{~b}$ & $29,123 \mathrm{a}$ & $14.5 \mathrm{a}$ & $22,117 \mathrm{a}$ & $16.4 \mathrm{a}$ & $1,193 \mathrm{a}$ & $0.05 \mathrm{~b}$ \\
\hline \multicolumn{11}{|l|}{ Plant density (plants/ha) } \\
\hline 102,000 & - & - & - & - & - & - & $10,250 \mathrm{a}$ & $9.8 \mathrm{a}$ & $2,071 \mathrm{a}$ & $0.18 \mathrm{a}$ \\
\hline \multicolumn{11}{|l|}{ Interactions } \\
\hline \multicolumn{11}{|l|}{ Cultivar $\times$ year } \\
\hline $\begin{array}{l}\text { Texas Grano } \\
1015 \mathrm{Y} \times 2006\end{array}$ & 488 & 0.03 & $-^{\mathrm{x}}$ & - & 29,598 & - & - & - & - & 0.06 \\
\hline 2007 & $6,505 * *$ & $0.37 * *$ & - & - & $15,937 * *$ & - & - & - & - & $0.30 * *$ \\
\hline Candy $\times 2006$ & 325 & 0.03 & - & - & 29,110 & - & - & - & - & 0.05 \\
\hline $2007 \times 100$ & - & - & - & - & 12,389 & - & - & - & - & - \\
\hline 400 & - & - & - & - & $15,279 \mathrm{NS}$ & - & - & 一 & - & - \\
\hline
\end{tabular}

${ }^{2}$ Values in a column with the same letter are not significantly different, $P<0.05$, Ryan-Einot-Gabriel-Walsh multiple range test.

y"_." = Values are linearly distributed.

$x "$ "_ = Interaction is not significant.

ss, ** Nonsignificant or significant at $P<0.01$, least squares means analysis.

transplants. An analysis of variance determined that cultivar, but not year, affected transplant dry weight (data not shown), and the data were pooled over year.

The cv. Texas Grano 1015 Y reached the harvest criterion ( $50 \%$ of tops broken over) at $94 \mathrm{~d}$ in both years, more quickly than did 'Candy', $104 \mathrm{~d}$ in 2006 and $113 \mathrm{~d}$ in 2007. Plants of 'Texas Grano $1015 \mathrm{Y}$ ' received $\approx 32$ and $47 \mathrm{~cm}$ of rain in 2006 and 2007, respectively, and plants of 'Candy' received $\approx 33$ and $76 \mathrm{~cm}$ in 2006 and 2007, respectively, with $\approx 62 \mathrm{~cm}$ of rain occurring in May and June 2007. Water to supplement precipitation was supplied twice in 2006, but irrigation was unnecessary in 2007. Average maximum, minimum, and overall average temperatures that plants of 'Texas Grano 1015 Y' were exposed to in 2006 were 25.6, 13.1, and 19.3 ${ }^{\circ} \mathrm{C}$, and in 2007 , these were $24.7,14.7$, and $19.7^{\circ} \mathrm{C}$. The average maximum temperature in 2007 was $\approx 4 \%$ cooler than in 2006 , whereas the average minimum and overall average temperatures were $\approx 5 \%$ and $2 \%$ warmer, respectively, than in 2006. Average maximum, minimum, and overall average temperatures that plants of 'Candy' were 27, 14.1 , and $20.7^{\circ} \mathrm{C}$, and in 2007 , these were 27.4 , 16.9 , and $21.8{ }^{\circ} \mathrm{C}$, respectively. The average maximum, minimum, and overall average temperatures in 2007 were $\approx 1.5 \%, 20 \%$, and $5.3 \%$ warmer than in 2006 , respectively.

Total marketable bulb number was affected by plant density; total marketable yield was affected by year, cultivar, plant density and the year $\times$ cultivar interaction (Table 2). Total numbers of marketable bulbs were equal in both years. In 2006, the total marketable yield was higher than in 2007. 'Candy' and 'Texas Grano 1015 Y' produced similar numbers of marketable bulbs, but 'Candy' had more marketable yield than did
'Texas Grano 1015 Y'. As plant density increased, total numbers of marketable bulbs produced and yield increased (Fig. 1). Almost all bulbs from plants established at the lowest density were marketable $(97 \%)$, but only $\approx 70 \%$ of bulbs produced at the other densities were marketable. For the interaction, marketable yield was similar for 'Candy' in both years but higher in 2006 for 'Texas Grano 1015 Y' than in 2007 (Table 3).

Year, cultivar, and plant density, but not fertilizer rate, and some of their interactions affected number and yield of categories of bulbs (Table 4). Year affected small and large bulb number and yield and cull yield. Cultivar affected all but cull number. Plant density affected number and yield of small, medium, and large bulbs and these relationships were distributed linearly. The year $\times$ cultivar interaction affected small and large numbers of bulbs and small bulb and cull yield. The year $x$ fertilizer rate interaction affected numbers of large bulbs.

Main effects influenced number and/or yield for some bulb categories (Table 5). There were a lower number of small bulbs, a higher large bulb yield, and a lower cull yield in 2006 than 2007. 'Texas Grano 1015 Y' had higher numbers of small, medium, and cull bulbs and yields, and 'Candy' had higher numbers and yield of large and jumbo bulbs. As density increased, numbers and yield of small, medium, and large bulbs increased linearly (Fig. 2). Numbers and yield of jumbo and culls were unchanged.

Interactions also affected some measures of yields for bulb categories (Table 5). For 'Texas Grano 1015 Y', numbers and yield of small bulbs were lower in 2006 than in 2007, but these same measures for 'Candy' were unaffected. In 2006, 'Texas Grano 1015 Y' had more large bulbs than in 2007, but for
'Candy', numbers of large bulbs were unaffected. Cull yields for 'Texas Grano 1015 Y' were lower in 2006 than in 2007, but those for 'Candy' were unaffected. In 2006, yields of large bulbs were higher when $100 \mathrm{~kg} \cdot \mathrm{ha}^{-1}$ of $\mathrm{N}$ was applied, but fertilizer level had no affect in 2007.

Content of most nutrients and soluble solids in bulbs were affected by year, and soluble solids were affected by cultivar (Table 6). Between years, there were no differences in TKN or TKP; levels of nitrate- $\mathrm{N}$, potassium, sodium, and $\mathrm{SO}_{4}$ were higher in 2006, and levels of nitrite-N, calcium, magnesium, $\mathrm{PO}_{4}$, and soluble solids were higher in 2007. In addition, soluble solids in 'Candy' (7.6) was higher than in 'Texas Grano 1015 Y' (6.9).

\section{Discussion}

Plant development can, in part, be affected by growing conditions, only some of which can be controlled by producers. How cultivars respond to the growing environment can affect growth, development, and nutrient content. Fertilizer rate can contribute to amount of yield and ultimately returns to profit. The efficiency of nutrient uptake can be dependent on numbers of plants in an area of ground. Within a genus, there can be differences in how individual plants in cultivars compete for available nutrients.

Nitrogen fertilizer rate or plant density did not affect bulb nutrient contents. This indicates plant density was not yet high enough to require additional nitrogen fertilizer or that the additional amount of fertilizer tested was not being adequately used. The high rate of nitrogen fertilizer did not provide a benefit to yield or bulb nutrient content and this is in contradiction to Maier et al. (1990a, 1990b). 

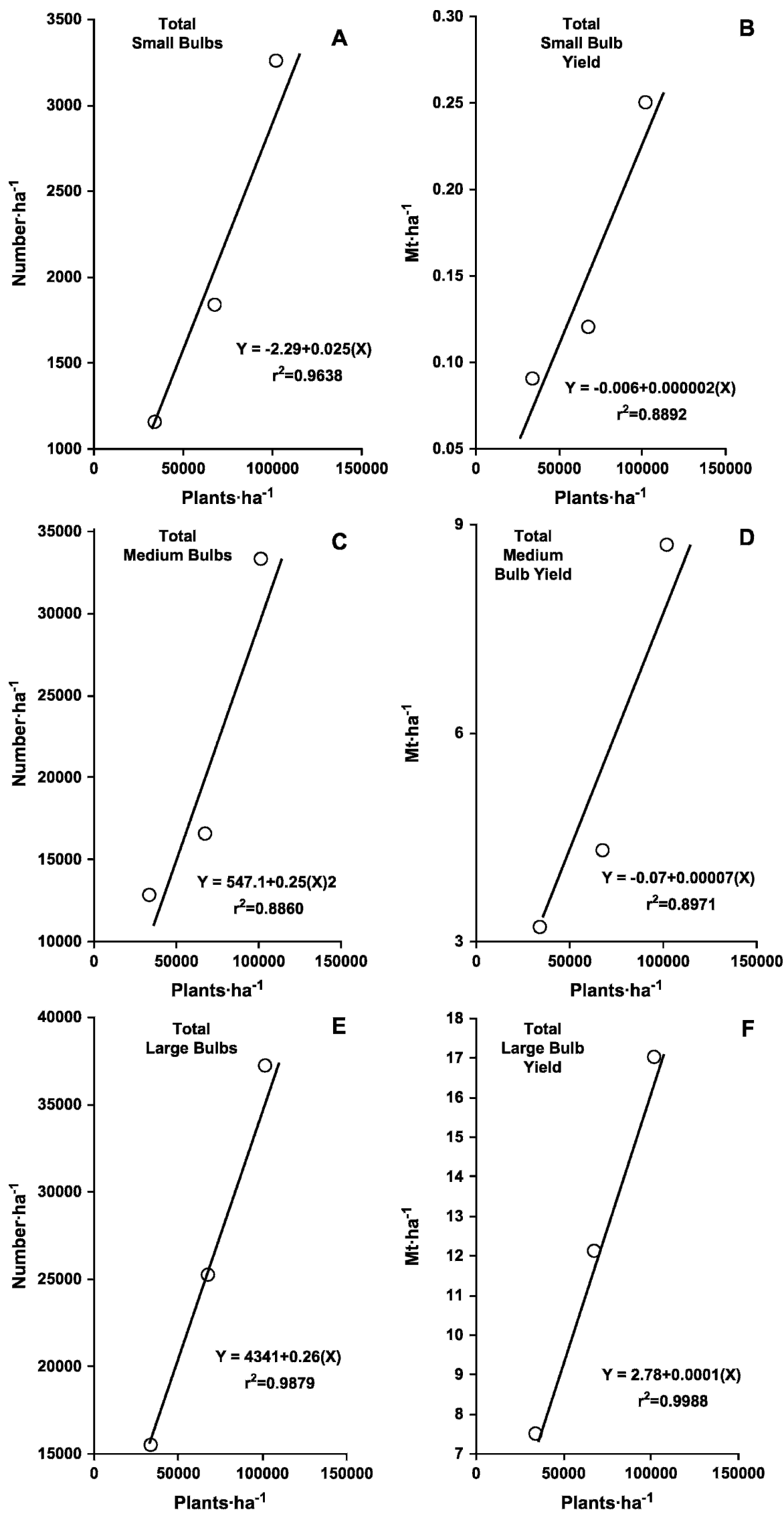

Fig. 2. Distribution of number and yield of: small (A), (B); medium (C), (D); and large (E), (F) bulbs from greenhouse-grown transplants.
It is possible that the recommended rate was too high, and the recommendation may need to be re-evaluated. The effect of year on most nutrients was likely the result of different environmental conditions. In both years, water availability was not a problem. However, high precipitation rates in 2007 may have affected nutrient availability and contributed to differences in content of some nutrients in the years. Although precipitation amount likely had an influence, other environmental factors could also have affected nutrient content such as air temperatures, which were overall warmer in 2007. The effects of environmental conditions on bulb nutrient condition need additional study.

Herison et al. (1993) increased yield by $25 \%$ by doubling the in-field plant density. This was accomplished by placing two seedlings in cells in trays in the greenhouse before plants were moved to the field. Magnitude of plant density was not directly related to similar magnitudes in yield increases. Yield of plants established at the lowest density was increased by $50 \%$ and $100 \%$ as plant density increased two or three times. Additional nitrogen fertilization had limited effects on yield; 'Candy' had reduced large bulb yield at the higher fertilizer rate. This seems to be generally in agreement with effects of nitrogen rate reported for seeded and bareroot onions (Boyhan et al., 2007; Díaz-Pérez et al., 2003; Shock et al., 2004).

Use of the best-adapted cultivar for growing conditions and market is a necessity when producing food crops. It appears that ' $\mathrm{Candy}$ ' was less affected by environmental conditions between years, i.e., yield of 'Candy' did not change between years, but 'Texas Grano 1015 Y' yield was reduced; numbers or yield of small, large, or cull bulbs for 'Candy' did not change, whereas numbers of small and cull bulbs increased and numbers of large bulbs of 'Texas Grano 1015 Y' decreased between years.

In 2006, a trial conducted on the same soil type in a different field at Lane, OK, evaluated yield of 'Candy' and 'Texas Grano 1015 Y' developed from hoop-house-grown transplants (Shrefler et al., 2007a). Plants in both trials were established within $1 \mathrm{~d}$ of each other. In the trial with hoop-house-grown transplants, a density equivalent to 68,000 plants/ha was used; harvest was 1 to $10 \mathrm{~d}$ later and yields were $\approx 20 \%$ less than for plants developed from transplants of the same cultivars produced in the greenhouse. The greenhouse-grown plants may have had a competitive advantage in terms of reduced transplant shock and better initial growth after transplanting because they had intact roots and actively growing tops.

There are sufficient differences in the literature to indicate that cultivar, location, and method of production may preclude adoption of a single method for onion production. Use of greenhouse-grown transplants for onion production is accompanied by problems and opportunities different from other methods using planting material produced in other ways. Greenhouse-grown transplants 
Table 6. Analysis of variance and effect of year on content of nutrients and soluble solids onions developed from greenhouse-grown transplants.

\begin{tabular}{|c|c|c|c|c|c|c|c|c|c|c|c|}
\hline Source & $\begin{array}{c}\text { Total } \\
\text { Nitrogen }\end{array}$ & Nitrate-N & Nitrite-N & $\mathrm{K}$ & Total Phosphorus & Phosphate & Calcium & Magnesium & Sodium & Sulfate & $\begin{array}{c}\text { Soluble } \\
\text { solids }\end{array}$ \\
\hline Year (Y) & NS & $* *$ & $* *$ & $* *$ & NS & $* *$ & $* *$ & $* *$ & $* *$ & $* *$ & $* *$ \\
\hline Cultivar (C) & NS & NS & NS & NS & NS & NS & NS & NS & NS & NS & $* *$ \\
\hline Nitrogen rate $(\mathrm{N})$ & NS & NS & NS & NS & NS & NS & NS & NS & NS & NS & NS \\
\hline Density (D) & NS & NS & NS & NS & NS & NS & NS & NS & NS & NS & NS \\
\hline Year & \multicolumn{10}{|c|}{$\mu g \cdot g^{-1}$ dry weight } & ${ }^{\circ}$ Brix \\
\hline 2006 & $1.0 \mathrm{a}^{\mathrm{z}}$ & $221.4 \mathrm{a}$ & $14.8 \mathrm{~b}$ & $2,698.4 \mathrm{a}$ & $0.29 \mathrm{a}$ & $210.1 \mathrm{~b}$ & $126.2 \mathrm{~b}$ & $49.8 \mathrm{~b}$ & $197.4 \mathrm{a}$ & $331.1 \mathrm{a}$ & $6.7 \mathrm{~b}$ \\
\hline 2007 & $1.2 \mathrm{a}$ & $12.2 \mathrm{~b}$ & $39.2 \mathrm{a}$ & $1,968.6 \mathrm{~b}$ & $0.49 \mathrm{a}$ & $315.8 \mathrm{a}$ & $397.9 \mathrm{a}$ & $143.6 \mathrm{a}$ & $105.1 \mathrm{~b}$ & $101.6 \mathrm{~b}$ & $7.7 \mathrm{a}$ \\
\hline
\end{tabular}

${ }^{z}$ Values in a column followed by the same letter are not significantly different, $t$ test.

ns, ** Nonsignificant or significant at $P<0.01$; analysis of variance; there were no significant interactions; density was not distributed linearly.

are uniform in size, have the potting media around the roots, and have actively growing roots and shoot at field establishment. This makes it unnecessary to size plants before establishment in the field. Yields from plants developed from greenhouse-grown transplants appear to be able to deliver yields equal to, or better than, those from hoophouse-grown, or perhaps even bareroot, planting material. In this study, the highest density of plants established at the recommended nitrogen fertilizer rate was best. Additional work is required to improve the production system to determine if the predicted yields can be achieved and if the recommended nitrogen fertilizer needs to be adjusted.

\section{Literature Cited}

Bleasdale, J.K.A. 1966. The effects of plant spacing on the yield of bulb onions (Allium cepa L.) grown from seed. J. Hort. Sci. 41:145153.

Boyhan, G., D. Granberry, and T. Kelley. 2001a. Onion production guide. Univ. of Georgia Bul. No. 1198.

Boyhan, G.E., W.M. Randle, A.C. Purvis, P.M. Lewis, R.L. Torrance, D.E. Curry, and D.O. Linton. 2001b. Evaluation of growth stimulants on short-day onions. HortTechnology 11:38-42.

Boyhan, G.E., R. Hicks, and C.R. Hill. 2006. Natural mulches are not very effective for weed control in onions. HortTechnology 16:523-526.

Boyhan, G.E., R.L. Torrence, and C.R. Hill. 2007. Effects of nitrogen, phosphorus, and potassium rates and fertilizer sources on yield and leaf nutrient status of short-day onions. HortScience 42:653-660.

Brewster, J.L. 1994. Onions and other vegetable Alliums. CAB Intl., Wallingford, UK.

Brewster, J.L. and P.J. Salter. 1980. The effect of plant spacing on the yield and bolting of two cultivars of overwintering bulb onions. J. Hort. Sci. 55:97-102.

Díaz-Pérez, J.C., A.C. Purvis, and J.T. Paulk. 2003. Bolting, yield, and bulb decay of sweet onion as affected by nitrogen nutrition. J. Amer. Soc. Hort. Sci. 128:144-149.

Gamiely, S., W.H. Randle, H.A. Mills, and D.A. Smittle. 1991. Onion plant growth, bulb quality, and water uptake following ammonium and nitrate nutrition. HortScience 26:10611063.

Hatterman-Valenti, H.M. and P.E. Hendrickson. 2006. Companion crop and planting configuration effect on onion. HortTechnology 16:12-15.

Herison, C., J.G. Masabni, and B.H. Zandstra. 1993. Increasing seedling density, age, and nitrogen fertilization increases onion yield. HortScience 28:23-25.

Kanton, R.A.L., L. Abbey, R.G. Hilla, M.A. Tabil, and N.D. January. 2002. Influence of transplanting age on bulb yield and yield components on onion (Allium cepa $\mathrm{L}$.). J. Veg. Crop Prod. 8:27-37.

Leskovar, D.I. and C.S. Vavrina. 1999. Onion growth and yield are influenced by transplant tray cell size and age. Sci. Hort. 80:133-143.

Maier, N.A., A.P. Dahlenburg, and T.K. Twigden. 1990a. Effect of nitrogen on the yield and quality of irrigated onions (Allium cepa L.) cv. Cream gold grown on siliceous sands. Australian J. Expt. Agr. 30:845-851.

Maier, N.A., A.P. Dahlenburg, and T.K. Twigden. 1990b. Assessment of the nitrogen status of onions (Allium cepa L.) cv. Cream Gold by plant analysis. Australian J. Expt. Agr. 30:853-859.

McCraw, D. 1990. Growing dry bulb onions from fall seeding in Oklahoma. Proc. Oklahoma Hort. Indust. Show. 9:176-178.

Motes, J.E. and W. Roberts. 1994. Fertilizing commercial vegetables. OSU Extension Facts, F-6000. Oklahoma State University, Stillwater, OK.

Russo, V.M. 2004. Greenhouse-grown transplants as an alternative to bare-root transplants for onions. HortScience 39:1267-1271.

Russo, V.M. and S.V. Karmakar. 1998. Water extraction of plant tissues for analysis by ion chromatography. Commun. Soil Sci. Plant Anal. 29:245-253.

Shock, C.C., E.B.G. Feibert, and L.D. Saunders. 2004. Plant population and nitrogen fertiliza- tion for subsurface drip-irrigated onion. HortScience 39:1722-1727.

Shock, C.C., E.B.G. Feibert, and L.D. Saunders. 2005. Onion response to drip irrigation intensity and emitter flow rate. HortTechnology 15:652-659.

Shock, C.C., L.B. Jensen, J.H. Hobson, M. Seddigh, B.M. Shock, L.D. Saunders, and T.D. Stieber. 1999. Improving onion yield and market grade by mechanical straw application to irrigation furrows. HortTechnology 9:251-253.

Shrefler, J. 2001. Onion production in Oklahoma. Protc. Oklahoma-Arkansas Hort. Ind. Show. 21:106-107.

Shrefler, J. 2004. Onion variety selection, sources and quality. Protc. Oklahoma-Arkansas Hort. Ind. Show. 23:140-141.

Shrefler, J., T. Goodson, and S. McClure. 2007a. Hoop-house seeding date trial for onion transplant production. 2006 Vegetable Trial Report MP-164. Oklahoma State University, Stillwater, $\mathrm{OK}$.

Shrefler, J., T. Goodson, and P. Perkins-Veazie. 2007b. Onions: Transplant production, varieties, and storage trials. Protc. OklahomaArkansas Hort. Ind. Show. 26:119-121.

Singh, J. and C.S. Cramer. 2006. Is withholding irrigation during winter months detrimental to onion bulb quality? HortScience 41:1064.

Stoffella, P.J. 1996. Planting arrangement and density of transplants influence sweet Spanish onion yields and bulb size. HortScience 31:1129-1130.

U.S. Department of Agriculture, Agricultural Marketing Service. 1995. United States standards for grades of Bermuda-Granex-Grano type onions. Washington, DC. 8 July 2008. <http:// www.ams.usda.gov/standards/onsbgg.pdf $>$.

Vavrina, C.S. and F.M. Roka. 2000. Comparison of plastic mulch and bare-ground production and economics for short-day onions in a semitropical environment. HortTechnology 10:326330 .

Wang, G., M. Ngouajio, and D.D. Warncke. 2008. Nutrient cycling, weed suppression, and onion yield following Brassica and Sorghum sudangrass cover crops. HortTechnology 8:68-74. 